\title{
Analisis Kinerja Menggunakan Balance Scorecard Berdasarkan Metode Hitung Analytical Hierarchy Process (AHP) Di Puskesmas Astanagarib Kota Cirebon
}

\author{
Widya Jati Lestari ${ }^{1}$ \\ Universitas Catur Insan Cendekia \\ widya.jatilestari@cic.ac.id \\ Marsani Asfi \\ Universitas Catur Insan Cendekia \\ marsani.asfi@cic.ac.id \\ Fitri Sihombing ${ }^{3}$ \\ Universitas Catur Insan Cendekia \\ fitriyanisihombing46@yahoo.com
}

\begin{abstract}
Abstrak - Metode pengukuran kinerja perusahaan dengan menggunakan Balanced Scorecard merupakan strategi untuk meningkatkan produktivitas, tingkat efisiensi, dan persaingan. Penilaian kinerja mengolah masukan menjadi keluaran atau penilaian dalam penyusunan kebijakan, program dan kegiatan yang dianggap penting serta berpengaruh pada pencapaian sasaran dan tujuan . Hasil dari penilaian kinerja ini menjadi dasar penilaian keberhasilan dan kegagalan pelaksanaan kegiatan sesuai dengan sasaran dan tujuan yang telah ditetapkan. Penelitian ini bertujuan untuk mengetahui sistem pengukuran kinerja di Puskesmas Astanagarib Kota Cirebon berdasarkan Balance Scorecard. Pembobotan elemen kinerja dilakukan dengan metode Analytical Hierarchy Process (AHP). Pengumpulan data diawali dengan penilaian terhadap visi, misi, dan strategi puskesmas. Data yang diperoleh kemudian diolah dengan metode AHP. Pengumpulan data tiap perspektif menggunakan kuesioner, wawancara dan data dari Puskesmas. Metode AHP menerapkan pengambilan keputusan berdasarkan sejumlah kriteria dan alternatif yang dipilih berdasarkan pertimbangan semua kriteria dalam bentuk hierarki. AHP menerapkan metode analisis dan sintesis yang membantu proses pengambilan keputusan dan membantu dalam menetapkan prioritas-prioritas dan membuat keputusan berdasarkan aspek kualitatif dan kuantitatif yang harus dipertimbangkan. Tahapan analisis dibuat dalam bentuk aplikasi yang dapat memudahkan analisis kinerja Puskesmas. Dari hasil perhitungan dapat disimpulkan bahwa pengukuran kinerja di Puskesmas Astanagarib dengan menggunakan metode Balanced Scorecard dan metode hitung Analytical Hierarchy Process (AHP) menunjukkan bahwa kinerja di Puskesmas tersebut sudah baik, dinilai dari tiga perspektif yang diukur dengan bobot 0,39 untuk proses bisnis internal, pembelajaran dan pertumbuhan 0,22 . Hasil evaluasi kinerja Puskesmas cukup baik dengan skor 0,99.
\end{abstract}

Kata kunci-AHP; proses bisnis internal; pembelajar dan pertumbuhan; kinerja.

Abtract - The method of measuring company performance using the Balanced Scorecard is a strategy to increase productivity, efficiency levels, and competition. 
Performance appraisal processes input into outputs or assessments in the formulation of policies, programs and activities that are considered important and have an effect on the achievement of goals and objectives. The results of this performance appraisal form the basis for assessing the success and failure of implementing activities in accordance with predetermined goals and objectives. This study aims to determine the performance measurement system at the Astanagarib Health Center Cirebon City based on the Balance Scorecard. The weighting of the performance elements is carried out using the Analytical Hierarchy Process (AHP) method. Data collection begins with an assessment of the vision, mission, and strategy of the puskesmas. The data obtained were then processed using the AHP method. Collecting data for each perspective using a questionnaire, interviews and data from the Puskesmas. The AHP method applies decision making based on a number of criteria and alternatives selected based on the consideration of all criteria in a hierarchical form. AHP applies analysis and synthesis methods that assist the decision-making process and assist in setting priorities and making decisions based on qualitative and quantitative aspects that must be considered. The stages of analysis are made in the form of applications that can facilitate analysis of the performance of Puskesmas. From the calculation results, it can be concluded that the performance measurement at the Astanagarib Health Center using the Balanced Scorecard method and the Analytical Hierarchy Process (AHP) calculation method shows that the performance at the Puskesmas is good, judged from three perspectives measured with a weight of 0.39 for internal business processes. learning and growth 0.22 . The results of the Puskesmas performance evaluation are quite good with a score of 0.99 .

Keywords - AHP; internal business processes; learning and growth; performance.

\section{PENDAHULUAN}

Manajemen Strategi merupakan rangkaian kegiatan pengambilan keputusan secara mendasar dan menyeluruh, disertai penetapan cara melakukannya, yang dibuat oleh pimpinan dan diimplementasikan oleh jajaran dalam organisasi untuk mencapai tujuan (Sedarmayanti, 2014). Penetapan cara untuk menentukan strategi perusahaan dapat dilakukan dengan mengukur kinerja perusahaan.

Pengukuran kinerja perusahaan dapat dilakukan dengan standarisasistandarisasi yang telah ditentukan oleh perusahaan sendiri, pemerintah atau lembaga terkait. Masing-masing standar memiliki acuan penilaian yang berbedabeda sesuai dengan karakteristik dari standar acuan kinerja tersebut.
Pengukuran kinerja didasarkan dari hasil suatu penilaian yang sistematik dengan kelompok indikator kinerja kegiatan berupa indikator-indikator masukan, keluaran, hasil, manfaat dan dampak (Amins, 2009). Penilaian kinerja mengolah masukan menjadi keluaran atau penilaian yang dianggap penting serta berpengaruh pada pencapaian sasaran dan tujuan. Hasil dari penilaian kinerja ini menjadi dasar penilaian keberhasilan dan kegagalan pelaksanaan kegiatan sesuai dengan sasaran dan tujuan yang telah ditetapkan. Menurut Kaplan (Kaplan \& Norton, 2000) metode pengukuran kinerja yang bisa digunakan adalah Balanced Scorecard (BSC). Konsep Balanced Scorecard menilai kinerja keuangan akibat atau hasil dari kinerja non keuangan (pelanggan, proses bisnis internal, serta proses pembelajaran dan pertumbuhan) (Kaplan \& Norton, 
2000). Kerangka kerja Balanced Scorecard terdiri dari empat prespektif yang meliputi: financial prespective, costumer prespective, internal business process prespective dan learning and growth prespective (Kaplan \& Norton, 2000).

Beberapa penelitian yang dilakukan tentang kinerja perusahaan menggunakan metode BSC dan pembobotan AHP yaitu di PT ABC (Panudju et al., 2016). Penilaian kinerja di PT ABC dilakukan dari perspektif keuangan, pelanggan, proses bisnis internal, serta pembelajaran dan pertumbuhan. Pembobotan dan elemenelemen yang terdapat dalam pengukuran kinerja dilakukan dengan menggunakan metode Analytical Hierarchy Process (AHP). Hasil penelitian menunjukkan bahwa perspektif proses bisnis internal mempunyai bobot terbesar yaitu sebesar 0,350 . Hal ini menunjukkan bahwa perusahaan harus lebih memfokuskan pada peningkatan bisnis internal, meningkatkan kualitas produk dan efektivitas operasi dalam menghasilkan produk serta pengembangan jaringan rantai pasok (Panudju et al., 2016). Penelitian lainnya dilakukan Sari (Sari et al., 2018) tentang penerapan Key Performance Indicator (KPI) yang digunakan dari perspektif organisasi, proses dan staff. Pembobotan KPI dengan Analytical Hierarchy Process. Objective Matrix dan Traffic Light System digunakan untuk sistem penskoran. Penelitian tersebut menggunakan $23 \mathrm{KPI}$. Hasil penelitian diperoleh pemetaan nilai KPI dalam beberapa zona, yaitu zona merah, zona kuning dan zona hijau (Sari et al., 2018). Penelitian lainnya dilakukan Sumani (Sumani, 2016) dengan pendekatan balanced scorecard melalui perspektif keuangan, perspektif kepuasan pelanggan, perspektif bisnis internal dan perspektif pertumbuhan dan pembelajaran. Hasil penelitian menunjukkan bahwa perspektif yang berpengaruh terhadap kinerja bisnis adalah perspektif pelanggan. Namun, perspektif bisnis internal memiliki bobot penilaian terkecil pada hasil analisis AHP (Sumani, 2016).

Penelitian lainnya dilakukan oleh Retnawati (Retnawati, 2017) adalah tentang perancangan kinerja sistem informasi dengan metode Balanced Scorecard dan Analytical Hierarchy Process untuk suatu universitas. Perspektif yang digunakan adalah perspektif pelanggan, perspektif proses bisnis internal, perspektif pembelajaran dan pertumbuhan serta perspektif keuangan. Hasil penelitian menghasilkan persentase perspektif pelanggan $(42,8 \%)$, perspektif proses bisnis internal $(35,0 \%)$, perspektif pertumbuhan dan pembelajaran $(14,4 \%)$, dan perspektif keuangan $(7,8 \%)$ (Retnawati, 2017).

Penelitian penggunaan metode hitung AHP juga dilakukan oleh Marsani (Asfi \& Purnamasari, 2010) dan (Asfi et al., 2013), penelitian dilakukan berkaitan dengan penilaian pembobotan hirarki untuk seleksi mahasiswa dan dosen berprestasi dengan proses penentuan urutan prioritas kriteria untuk prestasi belajar siswa, menentukan bobot masingmasing calon siswa berprestasi, membuat matriks dengan isi urutan kriteria prioritas dan bobot kemudian dihitung dengan metode AHP. Hasil akhir dari prestasi siswa berprioritas global digunakan sebagai alat pemilihan keputusan oleh STMIK CIC (Asfi \& Purnamasari, 2010). Untuk penelitian dosen berprestasi, kriteria yang dijadikan rujukan penilaian adalah kuesioner dosen, meeting attendance, penelitian dan pengabdian masyarakat, serta exam score submission (Asfi et al., 2013).

Dari penelitian-penelitian sebelumnya fokus penelitian ini menekankan pada 4 perspektif dalam BSC dan metode AHP dengan obyek 
penelitian di beberapa bidang usaha dan pendidikan. Dalam penelitian ini, fokus penilaian kinerja didasarkan pada tiga perspektif yaitu perspektif pelanggan, perspektif proses bisnis internal, perspektif pembelajaran dan pertumbuhan. Objek data yang digunakan adalah di pemerintahan, yaitu PUSKESMAS Astanagarib di Kota Cirebon. Pengumpulan data tiap perspektif menggunakan kuesioner, wawancara dan data dari Puskesmas Astanagarib. Perhitungan bobot tiap perspektif mengacu pada metode Analytical Hierarchy Process (AHP). Metode AHP menerapkan pengambilan keputusan berdasarkan sejumlah kriteria dan alternatif yang dipilih berdasarkan pertimbangan semua kriteria dalam bentuk hierarki. AHP menerapkan metode analisis dan sintesis yang membantu proses pengambilan keputusan dan membantu dalam menetapkan prioritas-prioritas dan membuat keputusan berdasarkan aspek kualitatif dan kuantitatif yang harus dipertimbangkan.

\section{KAJIAN LITERATUR}

\section{Penilaian Kinerja}

Pengukuran kinerja didasarkan dari hasil suatu penilaian yang sistematik dengan indikator kinerja masukan, keluaran, hasil, manfaat dan dampak dari suatu kegiatan (Amins, 2009). Penilaian kinerja akan mengolah masukan menjadi keluaran sebagai dasar penilaian dalam penyusunan kebijakan/program/kegiatan sehingga berpengaruh pada pencapaian sasaran dan tujuan. Hasil penilaian kinerja menjadi dasar penilaian keberhasilan dan kegagalan pelaksanaan kegiatan sesuai dengan sasaran dan tujuan yang telah ditetapkan (Amins, 2009).

\section{PUSKESMAS}

Puskesmas menyelenggarakan upaya kesehatan masyarakat (UKM) dan upaya kesehatan perorangan (UKP) tingkat pertama melalui upaya promotif dan preventif (Permenkes. 2014., 2014). Kinerja pelayanan kesehatan puskesmas yaitu penyelenggaraan pelayanan Puskesmas, kepemimpinan dan manajemen Puskesmas, peningkatan mutu Puskesmas, upaya puskesmas yang berorientasi sasaran, kepemimpinan dan manajemen upaya puskesmas, sasaran kinerja dan MDG's, layanan klinis yang berorientasi Pasien, manajemen penunjang layanan klinis, peningkatan mutu klinis dan keselamatan Pasien (Permenkes. 2014., 2014).

\section{Balanced Score Card}

Konsep Balanced Scorecard menilai kinerja keuangan akibat atau hasil dari kinerja non keuangan (pelanggan, proses bisnis internal, serta proses pembelajaran dan pertumbuhan) (Kaplan \& Norton, 2000). Kerangka kerja Balanced Scorecard terdiri dari empat prespektif yang meliputi: financial prespective, costumer prespective, internal business process prespective dan learning and growth prespective (Tunggal, 2002).

Aspek dari standar akreditasi puskesmas memiliki hubungan dengan beberapa perspektif dalam Balanced Scorecard, yaitu :

a. Perspektif pelanggan yaitu layanan klinis yang berorientasi Pasien, peningkatan mutu klinis dan keselamatan Pasien.

b. Perspektif proses internal bisnis yaitu upaya puskesmas yang berorientasi sasaran, kepemimpinan dan manajemen Puskesmas, manajemen penunjang layanan klinis.

c. Perspektif pembelajaran dan pertumbuhan yaitu peningkatan mutu puskesmas, sasaran kinerja dan MDG's. 
Dari penelitian sebelumnya, tujuan dari penelitian ini adalah mengetahui kinerja Puskesmas melalui perspektif pelanggan, perspektif internal bisnis, serta perspektif pembelajaran dan pertumbuhan. Metode hitung kinerja menggunakan AHP. Penelitian ini juga menghasilkan luaran suatu aplikasi yang dapat digunakan dalam antar muka penilaian kinerja PUSKEMAS.

\section{METODE PENELITIAN}

\section{Tahapan Penelitian}

Pada penelitian ini, dibagi menjadi 2 tahapan utama, yaitu tahapan metode balanced scorecard untuk pengumpulan data awal. Tahapan kedua adalah penggunaan metode hitung AHP untuk menentukan penilaian kinerja. Gambar 1 menunjukkan gambaran umum tahapan pengukuran kinerja dengan 2 bagian utama. Tahapan pertama, terdiri dari penyusunan kuesioner, pengelompokan daftar pertanyaan berdasarkan ketiga perspektif BSC dan penyebaran kuesioner. Tahapan kedua dilakukan perhitungan dengan metode AHP, yang terdiri dari penentuan kriteria, sub kriteria dan alternatif untuk AHP.

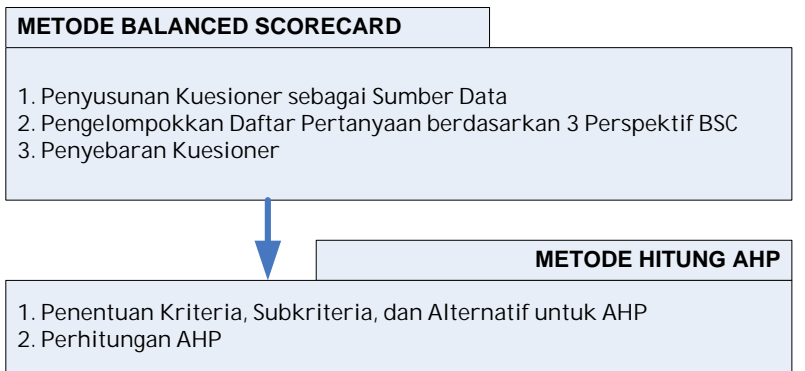

Gambar 1. Gambaran umum tahapan penelitian

\section{Penyusunan Kuesioner}

Penyusunan Kuesioner disusun berdasarkan perspektif dalam Balanced Scorecard yaitu perspektif internal proses bisnis, pelanggan, pembelajaran dan pertumbuhan.

\section{Pengelompokan Daftar Pertanyaan}

Daftar pertanyaan yang disusun dikelompokkan dalam 3 perspektif BSC. Tabel 1 merupakan hasil pengelompokan jumlah pertanyaan dalam 3 perspektif BSC.

Tabel 1.

Jumlah Pertanyaan Sesuai Perspektif BSC

\begin{tabular}{|c|l|c|}
\hline No & \multicolumn{1}{|c|}{ Kriteria } & $\begin{array}{c}\text { Jumlah } \\
\text { Pertanyaan }\end{array}$ \\
\hline 1 & Perspektif Pelanggan & 35 \\
\hline 2 & $\begin{array}{l}\text { Perspektif Internal Proses } \\
\text { Bisnis }\end{array}$ & 12 \\
\hline 3 & $\begin{array}{l}\text { Perspektif Pembelajaran } \\
\text { dan Pertumbuhan }\end{array}$ & 20 \\
\hline
\end{tabular}

\section{Penyebaran Kuesioner}

Penyebaran kuesioner ditentukan berdasarkan sumber data yang diinginkan, yaitu pasien dan pegawai. Kuesioner internal proses bisnis dan kuesioner pelanggan diberikan kepada pasien. Kuesioner pembelajaran dan pertumbuhan diberikan untuk pegawai Puskesmas. Sampel untuk responden terdiri dari 50 pasien dan 25 pegawai di Puskesmas. Skala jawaban dari masingmasing pertanyaan adalah 1 sampai dengan 5 yaitu sangat tidak baik, tidak baik, cukup baik, baik, dan sangat baik.

\section{Penentuan Komponen untuk AHP}

Tabel 2 menunjukkan komponenkomponen AHP yang dibentuk. Komponen-komponen tersebut yaitu :

1. Kriteria : internal proses bisnis, pelanggan dan pembelajaran dan pertumbuhan.

2. Sub kriteria : kriteria internal proses bisnis terdiri dari sub kriteria sarana prasarana dan proses. Kriteria pelanggan terdiri dari bukti fisik, keandalan, daya tanggap, jaminan dan empati. Kriteria pembelajaran dan pertumbuhan dengan sub kriteria kemampuan dan motivasi. 
Tabel 2.

\begin{tabular}{|c|c|c|}
\hline No & Perspektif BSC & Indikator \\
\hline & & Bukti Fisik (P11) \\
\hline & & $\begin{array}{l}\text { Kehandalan } \\
\text { (P12) }\end{array}$ \\
\hline 1 & $\begin{array}{l}\text { Perspektif } \\
\text { Pelanggan (P1) }\end{array}$ & $\begin{array}{l}\text { Daya Tanggap } \\
\text { (P13) }\end{array}$ \\
\hline & & Jaminan (P14) \\
\hline & & Empati (P15) \\
\hline 2 & Perspektif Internal & $\begin{array}{l}\text { Sarana } \\
\text { prasarana (P21) }\end{array}$ \\
\hline & Proses Bisnis(P2) & Proses (P22) \\
\hline 3 & $\begin{array}{l}\text { Perspektif } \\
\text { Pembelajaran dan }\end{array}$ & $\begin{array}{l}\text { Kemampuan } \\
\text { (P31) }\end{array}$ \\
\hline & Pertumbuhan (P3) & Motivasi (P32) \\
\hline
\end{tabular}

\section{Struktur Hierarki model AHP}

Gambar 2, merupakan struktur hierarki AHP yang dibuat berdasarkan perspektif BSC dan pertanyaanpertanyaan dari kuesioner yang menjadi sub kriteria/indikator.

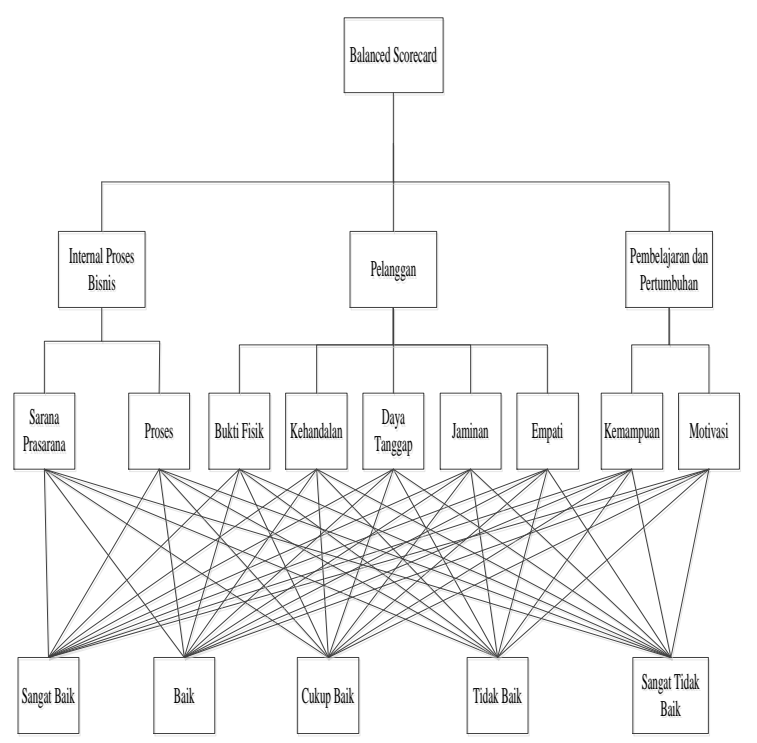

Gambar 2. Pohon hierarki komponen AHP

Gambar 2 menunjukkan prinsip dekomposisi struktur masalah yang kompleks dibagi menjadi bagian-bagian secara hierarki. Dekomposisi masalah adalah langkah dimana suatu tujuan yang telah ditetapkan selanjutnya diuraikan secara sistematis kedalam struktur yang menyusun rangkaian sistem hingga tujuan dapat dicapai secara rasional (Asfi \& Purnamasari, 2010).

\section{Analisa dan Perancangan Sistem}

Analisa dan perancangan sistem dilakukan dengan :

1. Mengidentifikasi sistem pengukuran kinerja tahun sebelumnya, sebagai latar belakang dan bahan perancangan sistem pengukuran kinerja yang baru dengan metode Balanced Scorecard.

2. Mengidentifikasi sasaran dan ukuran strategi berdasarkan 3 perspektif dalam Balanced Scorecard melalui studi literatur, data, kuesioner untuk pasien dan pegawai

3. Mengidentifikasi ukuran strategi berdasarkan 3 perspektif dalam Balanced Scorecard melalui studi literatur, data, kuesioner untuk pasien dan pegawai.

4. Melakukan perancangan indikator kinerja untuk mengukur kinerja puskesmas dengan perspektif Balanced Scorecard.

5. Pembobotan prioritas indikator kinerja dengan metode Analytical Hierarchy Process (AHP).

\section{HASIL dan PEMBAHASAN}

\section{Penentuan Kriteria untuk AHP}

Nilai kriteria untuk AHP diperoleh dari nilai rata-rata hasil menjumlahkan nilai $\mathrm{K} 1$ dari responden 1 sampai responden 50 , kemudian dibagi dengan jumlah responden yaitu 50 .

Tabel 3. Penentuan Kriteria Untuk Ahp

\begin{tabular}{|l|c|}
\hline \multicolumn{1}{|c|}{ Kriteria } & $\begin{array}{c}\text { Nilai } \\
\text { Rata-Rata }\end{array}$ \\
\hline Perspektif Pelanggan (P1) & 4,09 \\
\hline $\begin{array}{l}\text { Perspektif Internal Proses Bisnis } \\
\text { (P2) }\end{array}$ & 4,03 \\
\hline $\begin{array}{l}\text { Perspektif Pembelajaran dan } \\
\text { Pertumbuhan (P3) }\end{array}$ & 2,32 \\
\hline
\end{tabular}


Tabel 3, menunjukkan hasil penentuan nilai rata-rata untuk masingmasing kriteria seperti pada Tabel 3.

\section{Penentuan Subkriteria Perspektif Internal Proses Bisnis untuk AHP}

Field kuesioner merupakan pertanyaan dari perspektif pelanggan pada tabel 4.

Tabel 4. Penentuan Subkriteria Perspektif Internal Proses Bisnis untuk AHP

\begin{tabular}{|l|l|c|}
\hline \multicolumn{1}{|c|}{ Subkriteria } & \multicolumn{1}{|c|}{$\begin{array}{c}\text { Kuesioner } \\
\text { Nomor }\end{array}$} & $\begin{array}{c}\text { Nilai } \\
\text { Rata-rata }\end{array}$ \\
\hline $\begin{array}{l}\text { Sarana } \\
\text { Prasarana }\end{array}$ & $\begin{array}{l}1,4,18,19, \\
30,31,32\end{array}$ & 3,95 \\
\hline Proses & $\begin{array}{l}2,3,4,25, \\
27,28\end{array}$ & 4,16 \\
\hline
\end{tabular}

\section{Penentuan Subkriteria Perspektif Pelanggan untuk AHP}

Field kuesioner merupakan pertanyaan dari perspektif pelanggan pada tabel 5 .

Tabel 5. Konversi Subkriteria Perspektif Pelanggan

\begin{tabular}{|l|l|c|}
\hline Subkriteria & $\begin{array}{c}\text { Kuesioner } \\
\text { Nomor }\end{array}$ & $\begin{array}{c}\text { Nilai Rata- } \\
\text { rata }\end{array}$ \\
\hline \multirow{3}{*}{ Bukti Fisik } & $\begin{array}{l}19,20,21, \\
22,24,25, \\
30,31,32, \\
33,34,35\end{array}$ & 4,02 \\
\hline Kehandalan & $\begin{array}{l}1,2,3,4,5, \\
23\end{array}$ & 4,17 \\
\hline Daya Tanggap & $6,7,8,9,29$ & 4,33 \\
\hline Jaminan & $\begin{array}{l}10,11,12, \\
13,27,28\end{array}$ & 4,34 \\
\hline Empati & $\begin{array}{l}14,15,16, \\
17,18,26\end{array}$ & 3,69 \\
\hline
\end{tabular}

Penentuan Subkriteria Perspektif Pembelajaran dan Pertumbuhan untuk AHP

Field kuesioner merupakan pertanyaan dari perspektif pelanggan pada tabel 6 .
Tabel 6. Penentuan Subkriteria Perspektif Pembelajaran dan Pertumbuhan untuk AHP

\begin{tabular}{|l|c|c|}
\hline \multicolumn{1}{|c|}{ Subkriteria } & Kuesioner & $\begin{array}{c}\text { Nilai Rata- } \\
\text { rata }\end{array}$ \\
\hline \multirow{3}{*}{ Kemampuan } & $\begin{array}{c}1,3,4,5,6,7, \\
\begin{array}{c}10,11,12, \\
13,14,15,16, \\
17,18,19,20\end{array}\end{array}$ & 2,25 \\
\hline Motivasi & $\begin{array}{c}1,2,3,6,7,8, \\
9,20\end{array}$ & 2,32 \\
\hline
\end{tabular}

\section{Perhitungan Bobot dengan AHP}

Perhitungan bobot dilakukan dengan perbandingan, yaitu membandingkan nilai kriteria, subkriteria dan alternatif dengan perbandingan berpasangan yang bertujuan menghasilkan skala kepentingan relatif dari kriteria, subkriteria dan alternatif tersebut. Perbandingan berpasangan dalam bentuk matriks jika dikombinasikan akan menghasilkan prioritas.

Tabel 7 merupakan perbandingan nilai kriteria BSC. Perbandingan nilai kriteria antara P1 (perspektif pelanggan) dengan P2 (perspektif internal proses bisnis) adalah 1,01. Angka ini diperoleh dari perbandingan nilai rata-rata $\mathrm{P} 1$ dengan P2.

Tabel 7. Perbandingan Nilai Kriteria

\begin{tabular}{|l|c|c|c|}
\hline Kriteria & P1 & P2 & P3 \\
\hline P1 & 1 & 1,01 & 1,76 \\
\hline P2 & 0,99 & 1 & 1,74 \\
\hline P3 & 0,57 & 0,58 & 1 \\
\hline
\end{tabular}

Hal yang sama dilakukan perbandingan untuk setiap subkriteria dari masing-masing perspektif BSC. Tabel 8 merupakan hasil perbandingan subkriteria dari perspektif pelanggan.

Tabel 8. Perbandingan Nilai Kriteria

\begin{tabular}{|l|c|c|c|c|c|}
\hline Subkriteria & P11 & P12 & P13 & P14 & P15 \\
\hline P11 & 1 & 0,96 & 0,96 & 1,13 & 1,04 \\
\hline P12 & 1,04 & 1 & 1 & 1,17 & 1,08 \\
\hline P13 & 1,04 & 1 & 1 & 1,18 & 1,08 \\
\hline P14 & 0,88 & 0,85 & 0,85 & 1 & 0,92 \\
\hline P15 & 0,96 & 0,93 & 0,93 & 1 & 1 \\
\hline
\end{tabular}


Hasil perbandingan subkriteria P15(empati) dan P13(daya tanggap) dari kriteria atau indikator perspektif pelanggan pada Tabel 8 menunjukkan nilai 0,93 .

\section{Mensintesa Nilai Prioritas}

Berdasarkan data dari matriks perbandingan berpasangan maka untuk menghitung priority vector pada setiap kriteria dan subkriteria. Priority vector merupakan hasil penjumlahan dari tiap kriteria/subkriteria yang terlebih dahulu dibagi dengan jumlah yang ada dibawahnya kemudian hasil penjumlah tersebut dibagi jumlah kriteria atau subkriteria.

Tabel 9 menunjukkan nilai prioritas vektor untuk masing-masing perspektif BSC.

Tabel 9. Nilai Prioritas Vektor Perspektif

\begin{tabular}{|l|c|}
\hline \multicolumn{1}{|c|}{ Perspektif BSC } & $\begin{array}{c}\text { Priority } \\
\text { Vector }\end{array}$ \\
\hline Pelanggan & 0,39 \\
\hline Internal Proses Bisnis & 0,39 \\
\hline Pembelajaran dan Pertumbuhan & 0,22 \\
\hline Jumlah & 1 \\
\hline
\end{tabular}

Sedangkan Tabel 10, menunjukkan nilai prioritas vektor indikator untuk masing-masing indikator sesuai dengan perspektif BSC. Terlihat pada Tabel 10 untuk indikator P21(sarana dan prasarana) nilia prioritasnya adalah 0,49.

Tabel 10. Nilai Prioritas Vektor Indikator

\begin{tabular}{|c|l|l|c|}
\hline No & $\begin{array}{l}\text { Perspektif } \\
\text { BSC }\end{array}$ & Indikator & $\begin{array}{c}\text { Priority } \\
\text { Vector }\end{array}$ \\
\hline \multirow{4}{*}{1} & \multirow{4}{*}{ P1 } & P11 & 0,20 \\
\cline { 3 - 4 } & & P12 & 0,21 \\
\cline { 3 - 4 } & & P13 & 0,21 \\
\cline { 3 - 4 } 2 & \multirow{2}{*}{2 P14 } & P15 & 0,18 \\
\cline { 3 - 4 } & & P21 & 0,2 \\
\cline { 3 - 4 } & & P22 & 0,49 \\
\hline
\end{tabular}

\begin{tabular}{|l|l|l|l|}
\hline \multirow{2}{*}{3} & \multirow{2}{*}{ P3 } & P31 & 0,51 \\
\cline { 3 - 4 } & & P32 & 0,49 \\
\hline
\end{tabular}

Dari Tabel 10, nilai priority vector tertinggi untuk indikator dari perspektif P1(pelanggan) adalah P12(keandalan) dan P13 (daya tanggap) dengan skor 0,21 . Jika merujuk ke kuesioner keandalan terkait dengan pelayanan kesehatan terhadap pasien sesuai yang dijanjikan dan tepat waktu. Pemeriksaan, pengobatan dan perawatan di Puskesmas Astanagarib dilakukan secara cepat dan tepat serta menyampaikan informasi mengenai pasien secara jelas. Pegawai Puskesmas Astanagarib Cirebon juga selalu maksimal dalam melayani pemulihan Pasien. Sedangkan, jika merujuk ke kuesioner daya tanggap terkait dengan pelayanan yang diberikan oleh dokter yang selalu tanggap dalam memberikan kesempatan bertanya kepada pasien, menanyakan keluhan pasien, menjawab keluhan pasien serta didukung dengan tenaga medis yang handal sehingga dapat menimbulkan kepercayaan pasien untuk sembuh dan pemahaman pegawai di Puskesmas mengenai keinginan Pasien.

Nilai priority vector tertinggi untuk indikator dari perspektif P2(internal proses bisnis) adalah 0,51. Nilai skor tertinggi ini mengacu pada P22(proses). Jika ditelusuri maka indikator proses bisnis mengacu pada proses pelayanan di Puskesmas Astanagarib Cirebon tepat waktu, proses pemeriksaan, pengobatan dan perawatan dilakukan secara tepat dan cepat. Sistem pelayanan terhadap pasien memberikan kinerja dengan baik dan proses pelayanan obat melalui resep yang diberikan oleh Dokter baik serta sesuai dengan penyakit pasien.

Tabel 11. Nilai Prioritas Vektor Indikator

\begin{tabular}{|l|l|l|l|l|l|}
\hline $\begin{array}{l}\text { Hasil } \\
\text { Akhir }\end{array}$ & P1 & P2 & P3 & $\begin{array}{l}\text { Eigen } \\
\text { Vektor }\end{array}$ & $\begin{array}{c}\text { Rangk } \\
\text { ing }\end{array}$ \\
\hline
\end{tabular}




\begin{tabular}{|l|c|c|c|c|c|}
\hline & & & & $\begin{array}{l}\text { Norma } \\
\text { lisasi }\end{array}$ & \\
\hline STB & 0,01 & 0,00 & 0,02 & 0,03 & 5 \\
\hline TB & 0,02 & 0,01 & 0,04 & 0,07 & 4 \\
\hline CB & 0,10 & 0,17 & 0,37 & 0,64 & 2 \\
\hline B & 0,28 & 0,38 & 0,33 & 0,99 & 1 \\
\hline SB & 0,18 & 0,23 & 0,23 & 0,64 & 2 \\
\hline
\end{tabular}

Dari Tabel 11 dapat disimpulkan bahwa skor tertinggi yaitu 0,99(baik), skor sangat baik dan cukup baik adalah 0,64 dan skor paling bawah yaitu sangat tidak baik 0,03 .

Sedangkan untuk indikator baik untuk masing-masing perspektif BSC pada Tabel 11 menunjukkan nilai P1(perspektif pelanggan) dengan skor 0,28. P2(internal proses bisnis) dengan skor 0.38. Skor untuk P3(pertumbuhan dan pembelajaran) adalah 0.33 .

Hasil penilaian kinerja Puskesmas menunjukkan kinerja yang baik dengan skor 0.99. Sedangkan untuk masingmasing indikator sesuai dengan perspektif BSC, yaitu :

1. Perspektif pelanggan dengan skor 0,39 .

2. Perspektif internal proses bisnis dengan skor 0,39

3. Perspektif pembelajaran dan pertumbuhan dengan skor 0,22.

\section{SIMPULAN}

Dari analisa BSC dan pengolahan data hasil kuesioner menggunakan metode hitung AHP, disimpulkan bahwa :

1. PUSKESMAS Astanagarib Kota Cirebon menunjukkan cukup baik dalam pengelolaan pelanggan dalam hal ini pasien dan stakeholder lainnya di puskesmas.

2. Dalam point pengelolaan pelanggan PUSKESMAS Astanagarib cukup baik
Dalam P12(keandalan) dan P13 (daya tanggap) terhadap pengelolaan pasien.

3. Selain itu proses pengelolaan dalam internal PUSKESMAS Astanagarib juga cukup baik ditandai dengan skor 0,39 dalam perhitungan AHP.

\section{PENUTUP}

Berdasarkan penelitian yang telah dilakukan selama membuat aplikasi analisis kinerja puskesmas dengan metode Analytic Hierarchy Process (AHP) menunjukkan bahwa kinerja di Puskesmas Astanagarib sudah baik dari tiga perspektif yang diukur. Perspektif pelanggan dan perspektif Internal Proses Bisnis mempunyai bobot 0,39, pembelajaran dan pertumbuhan 0,22 dan kinerja memiliki bobot 0,99.

Saran untuk pengembangan aplikasi pada waktu mendatang adalah: Sebaiknya penggunaan Balanced scorecard lebih lengkap. Selalu membackup data agar terhindar dari kemungkinan terjadinya kehilangan data penting yang disebabkan oleh kerusakan pada perangkat keras.

\section{DAFTAR PUSTAKA}

Amins, A. (2009). M anajemen Kinerja Pemerintah Daerah. LaksBang Pressindo.

Asfi, M., Lukita, C., \& Amroni. (2013). Sistem Penunjang Keputusan Seleksi Dosen Berprestasi menggunakan MetodeA nalytical Hierarchy Process (AHP). Konferensi $\mathrm{N}$ asional Sistem Informasi(KN SI) 2013, 1732-1736.

Asfi, M., \& Purnamasari, R. (2010). Sistem Penunjang Keputusan Seleksi Mahasiswa Berprestasi Menggunakan Metode AHP (Studi Kasus STMIK CIC). Jurnal Informatika-U K M aranatha, 6(2), 131- 
144.

H arvarindo. Jakarta.

Kaplan, R. S., \& Norton, D. P. (2000).

Balanced Scorecard: Menerapkan

strategi menjadi aksi. Jakarta:

Erlangga.

Panudju, A. T., A sfar, A . H., \& Fauziah, F.

(2016). Pengukuran Kinrja

Perusahaan Menggunakan Metode

Balanced Scorecard (BSC) Dengan

Pembobotan Analytical Hierarchy

Process (AHP) Di PT. ABC, TBK.

Integrasi Sistem Industri,

3(December), 55-65.

https:/ / doi.org/ 10.24853/ jisi.4.1.pp

$-p p$

Permenkes. 2014. (2014). Peraturan

M enteri Kesehatan Republik Indonesia

Nomor $75 \quad$ Tahun 2014.

https:/ / doi.org/ 10.1038/ 132817a0

Retnawati, L. (2017). Perancangan Kinerja

Sistem Informasi Dengan Metode

Balanced Scorecard Dan Analytical

Hierarchy Process. Jurnal IPTEK, 21(2), 35.

https:/ / doi.org/ 10.31284/ j.iptek.20

17.v21i2.154

Sari, R. A., Yuniarti, R., \& Safitri, F. R. N.

(2018). Evaluasi Kinerja Perusahaan

Berdasarkan Perspektif Organisasi, Proses, dan Staf Berbasis AHP dan OMAX. Jurnal Teknik Industri, 19(1), 49.

https:/ / doi.org/ 10.22219/ jtiumm.v ol 19.nol.52-60

Sedarmayanti. (2014). M anajemen Strategis (1st ed.). Refika A ditama.

Sumani, S. (2016). Pengukuran Kinerja Bisnis Melalui Pendekatan Balanced Scorecard Dan Analytical Hierarchy Process (Ahp). EKUITAS (Jurnal Ekonomi D an Keuangan), 20(4), 455. https:/ / doi.org/ 10.24034/ j25485024 .y2016.v20.i4.1842

Tunggal, A. W. (2002). Memahami Konsep Balanced Scorecard. Penerbit 